\title{
Identifikasi Sebaran Nikel Laterit dan Volume Bijih Nikel Menggunakan Korelasi Data Bor
}

\author{
Eltrit Bima Fitrian \\ Dosen Program Studi Teknik Sipil, Universitas Kristen Indonesia Paulus, Makassar, Indonesia \\ eltritbima@gmail.com
}

\begin{abstract}
ABSTRAK
Nikel yang merupakan salah satu bahan galian ekonomis yang terdapat di bumi ini tentunya perlu diketahui penyebarannya untuk dapat memberikan keuntungan secara ekonomis dan memenuhi permintaan di bidang perindustrian, mengingat pentingnya fungsi nikel yang sangat dibutuhkan oleh industri logam dunia. Tujuan dari penelitian ini adalah (1) mengidentifikasi penyebaran endapan nikel laterit pada daerah pertambangan PT.Vale indonesia, Sorowako Luwu Timur (2) mengetahui besar volume bijih nikel agar nantinya eksplorasi lanjut secara komersial dapat dilakukan. Untuk mengidentifikasi penyebaran nikel laterit maka digunakan korelasi data bor, data bor yang telah didapatkan diolah oleh Software ArGcis 9.3 sehingga diperoleh daerah sebaran endapan nikel pada lapisan - lapisan laterit. Kemudian untuk melihat penampang lapisan laterit nikel dalam 3 dimensi digunakan Software Surpac 6.1.2 sedangkan untuk mengetahui besar volume bijih nikel, digunakan metode Area Of Influence (Daerah Pengaruh). Penyebaran endapan nikel pada lapisan laterit dipengaruhi oleh bentuk topografi daerah penelitian dan kemiringan lereng. Sedangkan untuk hasil perhitungan total volume bijih nikel yang diperoleh pada tiap lapisan laterit adalah sebesar $2.913 .682 \mathrm{~m}^{3}$.
\end{abstract}

Kata Kunci : ArGcis 9.3, Surpac 6.1.2, Nikel laterit, Volume

\section{ABSTRACT}

Nickel, which is one of the economical minerals found on earth, of course needs to know its distribution to be able to provide economic benefits and meet industrial demand, given the importance of nickel's function, which is very much needed by the world metal industry. The aim of this study were (1) to identify the spread of laterite nickel deposits in the mining area of PT. Vale Indonesia, Sorowako East Luwu (2) to prepare large volumes of nickel ore for commercial exploration. To identify the distribution of nickel laterite, drill data is used, the drill data that has been obtained is processed by ArGcis 9.3 software to obtain the distribution area of nickel deposits in the laterite layers. Then to see the cross-section of the nickel laterite layer in 3 dimensions used Surpac 6.1 .2 software while to see the large volume of nickel ore, uses the Influence Area method. The distribution of nickel in the laterite layer is influenced by the topography and slope area of the research. Meanwhile, the calculation of the total volume of nickel ore obtained in each laterite layer is 2,913,682 m3.

Keywords : ArGcis 9.3, Surpac 6.1.2, Laterite nickel, Volume

\section{PENDAHULUAN}

Indonesia memiliki potensi sumber daya mineral yang sangat besar. Salah satu diantaranya adalah Nikel laterit. Nikel laterit adalah produk residual pelapukan kimia pada batuan ultramafik. Proses ini berlangsung selama jutaan tahun dimulai ketika batuan ultramafik tersingkap dipermukaan bumi [1]. Nikel laterit juga diartikan sebagai suatu endapan bijih nikel yang terbentuk dari proses laterisasi pada batuan ultramafik(peridotit, dunit dan serpentinit) yang mengandung $\mathrm{Ni}$ dengan kadar yang tinggi, yang pada umumnya terbentuk pada daerah tropis dan sub tropis [2].

Nikel mempunyai sifat tahan karat. Dalam keadaan murni nikel bersifat lunak, tetapi jika dipadukan (alloy) dengan besi, krom, dan logam lainnya dapat membentuk baja tahan karat yang keras. Perpaduan nikel, krom dan besi menghasilkan baja tahan karat (stainless steel) yang banyak diaplikasikan pada peralatan dapur (sendok, dan peralatan memasak), ornamen - ornamen rumah dan gedung, serta komponen industri [3].

Indonesia memiliki cadangan nikel terbesar di dunia, yang artinya Indonesia berperan penting dalam bahan baku nikel dunia, dimana Indonesia menghasilkan sebesar 72 ton $\mathrm{Ni}$ atau $52 \%$ dari cadangan $\mathrm{Ni}$ dunia [4].

Sorowako, yang terletak di kabupaten Luwu Timur Sulawesi Selatan menjadi salah satu penghasil utama nikel di Indonesia dan memiliki cadangan nikel yang 
Paulus Civil Engineering Journal

E- Jurnal Teknik Sipil UKI-Paulus Makassar

http://ojs.ukipaulus.ac.id/index.php/pcej
Volume 3 No.1, Maret, 2021

ISSN Online 2775 - 4529 berlimpah. Endapan lateritnya merupakan sumber utama logam nikel di Indonesia yang sampai saat ini masih di tambang dan diolah oleh PT. Vale Indonesia dengan menggunakan teknik peleburan konvensional. Nikel yang merupakan salah satu bahan galian ekonomis yang terdapat di bumi ini tentunya perlu diketahui penyebarannya untuk dapat memberikan keuntungan secara ekonomis dan memenuhi permintaan di bidang perindustrian, mengingat pentingnya fungsi nikel yang sangat dibutuhkan oleh industri logam dunia. Sehingga tujuan dari penelitian ini adalah untuk mengidentifikasi penyebaran nikel laterit dan mengetahui besar volume bijih nikel agar dapat mempermudah proses eksplorasi lanjut secara komersial dari suatu endapan dimana penelitian ini dilakukan pada salah satu area pertambangan PT. Vale Indonesia, yang berada di daerah Sorowako, Luwu Timur.

Untuk menjawab tujuan pertama dari penelitian ini, yaitu menentukan penyebaran nikel laterit, digunakan korelasi data bor yang merupakan parameter dilapangan dan sebagai data utama dari penelitian. Drilling / Pemboran mempunyai tujuan untuk mencari data bawah permukaan sehingga data core yang diperoleh dari pemboran nantinya dapat memberikan informasi penyebaran endapan nikel laterit di bawah permukaan bumi kemudian memperkirakan cadangannya. Pemboran yang dilakukan terbagi atas dua macam, yaitu:

a. Exploration Drilling (Pemboran Eksplorasi), dimana pemboran ini merupakan pemboran awal yang dilakukan dengan jarak $400 \mathrm{~m} x$ $400 \mathrm{~m}, 200 \mathrm{~m} \times 200 \mathrm{~m}$ dan $100 \mathrm{~m} \times 100 \mathrm{~m}$ pada titik bor yang telah dipersiapkan oleh surveyor. Surveyor memberikan informasi mengenai posisi/koordinat (east, north, dan elevasi).

b. Development Drilling (Pemboran Development), merupakan pemboran yang lebih detail dari pemboran awal yang dilakukan dengan jarak $50 \mathrm{~m} \times 50 \mathrm{~m}$ dan $25 \mathrm{~m} \times 25 \mathrm{~m}$.

Sedangkan untuk memperoleh besar volume bijih nikel maka dilakukan dengan menggunakan metode poligon. Metode ini didasarkan pada penentuan batas dari daerah pengaruh disekeliling suatu lubang bor,yang mencakup setengah dari daerah yang terletak diantara lubang yang berada disekelilingnya [5].

Beberapa peneliti sebelumnya yang meneliti mengenai sebaran nikel laterite antara lain, Identifikasi Sebaran Nikel Laterit Berdasarkan Hasil Test Pit di Kecamatan Kabaena Kabupaten Bombana Provinsi Sulawesi Tenggara oleh Nurliah Jafar [6], Pemetaan Sebaran Endapan Nikel Laterit Dengan Metoda Resistivitas di Daerah Gunung Tinggi Talaga Piru, Kabupaten Seram Bagian Barat Provinsi Maluku oleh Sisca Madonna Sapulete et.al [7], Estimasi Sumberdaya Nikel Laterit Dengan Metode Inverse Distance Weighting (IDW) pada PT. Vale Indonesia, tbk. Kecamatan Nuha Provinsi Sulawesi Selatan oleh Risma Mustika [8], Pengaruh Batuan Dasar dan Geomorfologi Terhadap Laterisasi dan Penyebaran Kadar $\mathrm{Ni}$ dan Fe Pada Endapan Nikel laterit PT. Tambang Bumi Sulawesi, Desa Pongkalaero, Kabupaten Bombana, Sulawesi Tenggara oleh Hasria et. Al [9], dan beberapa penelitian lainnya.

\section{METODOLOGI PENELITIAN}

Penelitian ini merupakan penelitian non-experimental menggunakan observasi langsung di lapangan. Data yang digunakan dalam penelitian ini yaitu data lubang bor sebanyak 160 titik lubang bor, dimana data - data ini berisikan data koordinat/posisi lubang bor yang terdiri dari data easting, northing dan elevasi serta data assay yang merupakan hasil analisis kadar nikel pada setiap titik lubang bor dengan interval kedalaman tertentu.

\section{Mengolah Data Assay dan Data Collar}

Pengolahan data terlebih dahulu dilakukan pada data Assay yang merupakan tabel data berisikan informasi mengenai data nama lubang bor, hasil analisis kadar nikel, hasil analisis kadar unsur kimia lain seperti magnesium atau besi, dan lain - lain dari lapisan limonit dan lapisan saprolit pada setiap interval kedalaman titik lubang bor. Sedangkan pada data collar berisikan data koordinat/posisi (easting, northing dan elevasi) titik lubang bor .

\section{Nilai Berat Kering (Dry Weight)}


Paulus Civil Engineering Journal

E- Jurnal Teknik Sipil UKI-Paulus Makassar

http://ojs.ukipaulus.ac.id/index.php/pcej

Untuk menentukan nilai berat kering (dry weight) nikel, dilakukan uji laboratorium pada data core, yaitu data yang berupa sampel batuan yang didapatkan dari setiap titik lubang bor di lapangan. Data sampel dikeringkan terlebih dahulu kemudian dilakukan penimbangan.

\section{Kadar Bijih Nikel}

Dalam eksplorasi, menentukan kadar bijih nikel adalah bagian terpenting untuk mengetahui besar volume bijih nikel. Untuk menentukan kadar bijih nikel, maka terlebih dahulu perlu diketahui kadar batas optimum atau COG (cut off grade) yang akan kita gunakan. COG (cut off grade) biasanya ditentukan berdasarkan permintaan pasar. Dalam hal ini, COG (cut off grade) yang digunakan oleh PT. Vale Indonesia adalah nilai kadar bijih nikel harus berkadar $<1.5 \%$ dan berada di kedalaman 2 meter. Setelah batas optimum diketahui maka selanjutnya adalah menentukan kadar bijih nikel dengan menggunakan persamaan :

$\frac{\sum \text { dry weight } \times \mathrm{Ni}}{\sum \text { dry total }}$

\section{Menghitung Ketebalan Bijih Nikel}

Ketebalan endapan bijih nikel ditentukan dengan menjumlahkan nilai interval bijih nikel pada setiap lubang bor berdasarkan kedalaman setiap lapisan yang dianggap sebagai bijih nikel yaitu yang telah memenuhi COG.

\section{Luas Daerah Pengaruh}

Dalam menentukan luas masing - masing daerah pengaruh, metode yang digunakan adalah dengan menghitung setengah luas daerah pengaruh yang berbeda disamping kiri dan kanan, atas dan bawah derah lubang bor sehingga membentuk suatu bujur sangkar [9].

Luas daerah pengaruh yang digunakan pada penelitian ini adalah dengan pemboran development (development drilling) dengan jarak detail yaitu $50 \mathrm{~m}$ x 50m.
Volume 3 No.1, Maret, 2021

ISSN Online 2775 - 4529

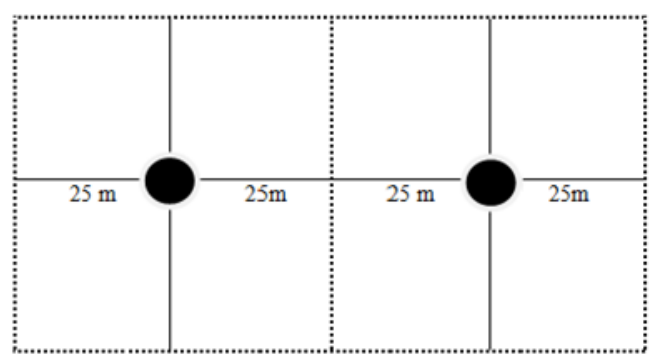

Gambar 1. Luas daerah pengaruh

Keterangan :

$=$ Titik bor

= Batas daerah pengaruh titik bor

\section{Volume Bijih Nikel}

Setelah luas daerah pengaruh masing - masing lubang bor diketahui, maka kita dapat mengestimasikan volumenya denggan menggunakan persamaan :

$\boldsymbol{V}=\boldsymbol{A} \times \boldsymbol{t}$

Dimana :

$\mathrm{V}=$ Volume daerah pengaruh $\left(\mathrm{m}^{3}\right)$

$A=$ Luas daerah pengaruh $\left(\mathrm{m}^{2}\right)$

$\mathrm{t}=$ Tebal bijih nikel $(\mathrm{m})$

dan untuk menghitung volume total dari masingmasing lubang bor, digunakan persamaan :

$\mathrm{V}_{\text {total }}=\mathrm{V} 1+\mathrm{V} 2+\mathrm{V} 3+\mathrm{V} 4 \ldots+\mathrm{Vn}$

Dimana :

$\mathrm{V} 1+\mathrm{V} 2+\mathrm{V} 3+\mathrm{V} 4+\ldots+\mathrm{Vn}=$ Volume masingmasing poligon $\left(\mathrm{m}^{3}\right)$

\section{Membuat Peta Sebaran Nikel}

Untuk mengetahui sebaran nikel laterit, maka penyebarannya dibuat dalam bentuk visual berupa peta sebaran. Untuk membuat peta sebaran nikel laterit, maka input data yang digunakan adalah data assay dan data collar yang berisikan data nama lubang bor, hasil analisis kadar nikel dan unsur lain serta data koordinat/posisi (easting, northing dan elevasi) pada masing - masing titik lubang bor. Data assay dan data collar kemudian diolah bersama dengan menggunakan software ArcGIS 9.3. Kemudian 
Paulus Civil Engineering Journal

E- Jurnal Teknik Sipil UKI-Paulus Makassar

http://ojs.ukipaulus.ac.id/index.php/pcei

untuk menampilkan ketebalan lapisan laterit yang berkorelasi dengan titik - titik bor dalam 3 dimensi, data input yang dibutuhkan juga berupa database berisikan informasi mengenai data assay, data litologi, data collar dan survei yang dibuat dengan bantuan software Ms.Excel 2013 dengan format comma separated value (CSV) yang kemudian data diimpor ke software Surpac 6.1.2.

\section{HASIL DAN PEMBAHASAN}

\section{Daerah Titik Bor}

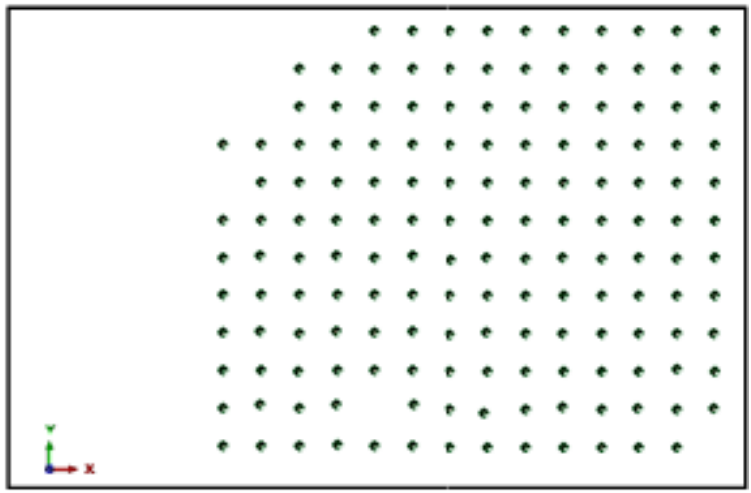

Gambar 2. Daerah titik bor

Gambar 2 merupakan titik - titik lubang bor pada area penelitian, dengan mengambil 160 titik bor. Jarak untuk setiap lubang bor adalah $50 \mathrm{~m} \times 50 \mathrm{~m}$ dimana titik - titik bor ini akan menjadi acuan dalam menentukan penyebaran nikel laterit.

\section{Penampang 3 Dimensi Korelasi Data Bor dan Lapisan Laterit}

Pembuatan penampang korelasi dilakukan untuk menentukan korelasi pada setiap lubang bor sehingga dapat ditentukan lapisan laterit pada lubang - lubang bor tersebut. Dari hasil penelitian, lapisan laterit pada data bor terdiri dari 3 lapisan yaitu lapisan limonit, saprolit dan bedrock.
Volume 3 No.1, Maret, 2021

ISSN Online 2775 - 4529

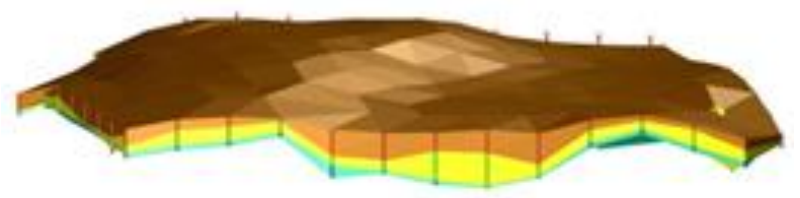

Gambar 3. Penampang 3D korelasi lapisan laterit

Gambar 3 merupakan gabungan korelasi titik - titik bor antara lapisan laterit yaitu limonit, saprolit dan bedrock dengan data bor. Lapisan teratas yang berwarna cokelat merupakan lapisan limonit, lapisan kedua yang berwarna kuning merupakan lapisan saprolit dan lapisan ketiga yang berwarna hijau merupakan lapisan bedrock. Pada gambar dapat terlihat bahwa untuk setiap lapisan laterit memiliki ketebalan yang berbeda - beda antara tiap lapisannya. Penyebab adanya perbedaan lapisan ini sebebakan oleh adanya pengaruh kondisi topografi pada daerah penelitian, sehingga menyebabkan ketebalan lapisan endapan yang berbeda - beda. Pada lereng dengan derajat sedang/landai, proses pengayaan akan berjalan dengan baik karena air akan meresap perlahan melalui rekahan dan pori batuan yang lebih dalam sehingga akan menghasilkan akumulasi endapan yang lebih tebal. Sedangkan pada lereng dengan derajat tinggi (terjal), air akan cenderung mengalir ke daerah yang lebih landai sehingga tidak memiliki kesempatan untuk meresap pada daerah terjal yang dilaluinya, hal ini menyebabkan proses pengayaan kurang intensif dan menghasilkan lapisan endapan yang terbentuk tipis atau tidak ada sama sekali.

\section{Sebaran Nikel Laterit}

Pada lapisan saprolit, secara kimiawi pada zona lapisan ini banyak terdapat unsur magnesium $(\mathrm{Mg})$ dan nikel ( $\mathrm{Ni})$ serta berkurangnya unsur besi $(\mathrm{Fe})$ yang banyak terdapat pada zona lapisan limonit. Penyebaran nikel bergantung dari arah aliran airan tanah dan sangat dipengaruhi oleh bentuk morfologinya. Gambar 4 merupakan peta sebaran nikel di lapisan saprolit, dimana lapisan ini merupakan lapisan pengayaan unsur nikel. Pada peta dapat terlihat, kadar nikel terbesar memiliki kadar diatas $1.7 \%$ yang diperlihatkan oleh warna merah pada peta. 
Paulus Civil Engineering Journal

E- Jurnal Teknik Sipil UKI-Paulus Makassar

http://ojs.ukipaulus.ac.id/index.php/pcej

Berdasarkan konturnya, umumnya tersebar pada daerah punggungan bukit.

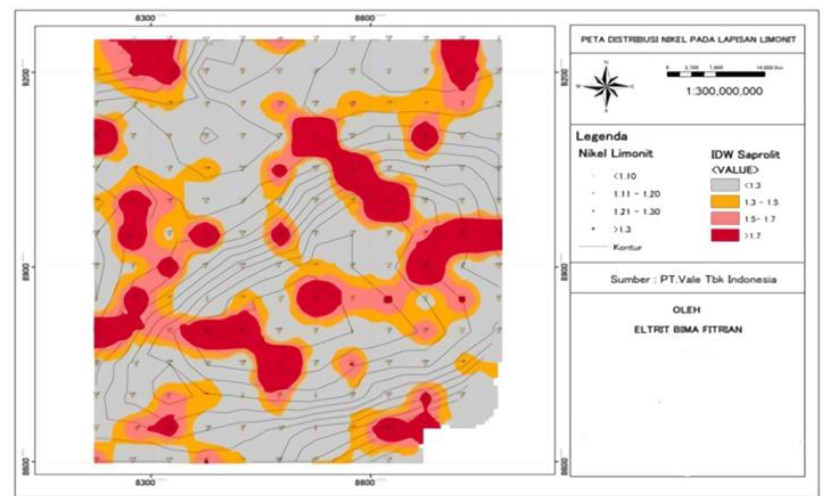

Gambar 4. Peta sebaran nikel pada lapisan saprolit

Sebaliknya untuk kadar nikel terendah yang terdapat di lapisan ini, kadar yang diperoleh kurang dari 1.1\% diperlihatkan oleh warna abu - abu pada peta. Sedangkan pada lapisan limonit unsur nikel (Ni) biasanya tidak memiliki kadar yang terlalu tinggi, hal ini disebabkan karena air akan membawa unsur nikel meresap lebih dalam ke zona saprolit dan hanya sebagian kecil yang berada tetap di lapisan limonit. Penyebaran nikel pada lapisan saprolit tidak merata antara nikel berkadar rendah dengan nikel berkadar tinggi disebabkan karena adanya pengaruh topografi pada daerah penelitian sehingga terjadi aktivitas pengikisan (erosi) yang membawa unsur nikel dan menyebabkan penyebaran dan proses pelapukan yang berbeda. Kontur daerah penelitian dapat dilihat pada gambar 4 .

Pada gambar, sebaran nikel lapisan saprolit menunjukkan lebih banyak nikel berkadar rendah yang tersebar pada daerah penelitian jika dibandingkan dengan nikel berkadar tinggi, hal ini disebabkan karena adanya kemungkinan unsur nikel tidak terakumulasi dengan baik pada daerah topografi dengan kemiringan lereng yang sangat landai.

\section{Kadar Bijih (Ore) Nikel}

Penentuan kadar bijih nikel pada setiap lubang bor merupakan bagian terpenting untuk dapat menentukan ketebalan bijih dan volume nikel. Kadar bijih nikel ditetapkan berdasarkan pada batas optimum atau COG (cut off grade) bijih nikel.
Volume 3 No.1, Maret, 2021

ISSN Online 2775 - 4529
Adapun nilai kadar bijih nikel yang digunakan oleh PT. Vale Indonesia yaitu kadar bijih nikel (ore) harus berkadar diatas $1.5 \%$ dan memiliki kedalaman 2 meter. Kemudian dengan menggunakan persamaan 1 perhitungan kadar nikel dapat dilakukan pada program Ms. Excel 2013.

\section{Ketebalan Bijih Nikel}

Perhitungan ketebalan bijih nikel (ore) ditentukan untuk mengetahui seberapa besar volume dari akumulasi kandungan bijih nikel pada setiap lubang bor. Ketebalan bijih nikel ditentukan berdasarkan kadar bijih nikel yang sesuai dengan COG (cut off grade) yakni kadar bijih nikel harus berada $<1.5 \%$ dengan kedalaman 2 meter untuk dapat disebut sebagai bijih nikel.

\section{Volume Bijih Nikel}

Dengan menggunakan hasil data pengeboran eksplorasi sebanyak 160 titik bor, selanjutnya dilakukan perhitungan volume bijih nikel. Setalah kadar dan ketebalan bijih nikel diperoleh untuk setiap titik bor, maka digunakan metode area of influence atau daerah pengaruh untuk menentukan volume bijih nikel, yaitu setiap titik bor diambil sejauh setengah jarak dari spasi titik bor di sekitarnya sehingga akan membentuk suatu bujur sangkar atau daerah pengaruh (area of influence).

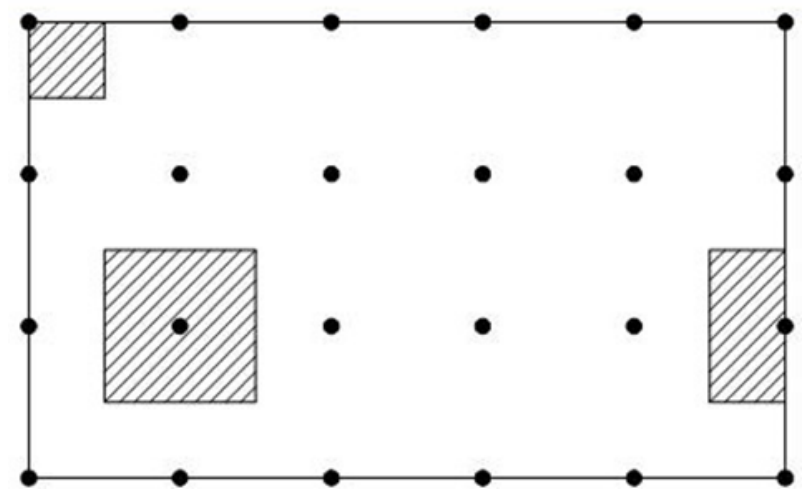

Gambar 5. Daerah Pengaruh titik bor

Acuan data bor pada penelitian ini adalah data logging bor spasi $50 \mathrm{~m} \times 50 \mathrm{~m}$. Sehingga untuk menghitung volume bijih nikel maka didapat dengan menggunakan persamaan 2. Luas blok dihitung berdasarkan bujur 
Paulus Civil Engineering Journal

E- Jurnal Teknik Sipil UKI-Paulus Makassar

http://ojs.ukipaulus.ac.id/index.php/pcej

sangkar yang terbentuk dari daerah pengaruh yaitu titik bor yang diambil adalah setengah jarak dari spasi titik bor di sekitarnya.

Tabel 1. Perhitungan volume bijih nikel

\begin{tabular}{ccccc}
\hline $\begin{array}{c}\text { Jenis } \\
\text { Lapisan }\end{array}$ & Hole ID & $\begin{array}{c}\text { Ketebalan } \\
(\mathrm{m})\end{array}$ & $\begin{array}{c}\text { Luas } \\
\left(\mathrm{m}^{2}\right)\end{array}$ & $\begin{array}{c}\text { Volume } \\
\left(\mathrm{m}^{3}\right)\end{array}$ \\
\hline Limonit & $\mathrm{C} 110221$ & 9 & 2.500 & 22.500 \\
& $\mathrm{C} 135163$ & 4 & 2.500 & 10.000 \\
& $\mathrm{C} 135200$ & 8 & 2.500 & 20.000 \\
& $\mathrm{C} 135353$ & 13 & 2.500 & 32.500 \\
& $\mathrm{C} 135354$ & 7 & 2.500 & 17.500 \\
& $\mathrm{C} 135355$ & 6 & 2.500 & 15.000 \\
\hline Saprolit & $\mathrm{C} 100221$ & 3.45 & & 86.250 \\
& $\mathrm{C} 135163$ & 5.30 & & 13.250 \\
& $\mathrm{C} 135200$ & 4 & & 10.000 \\
& $\mathrm{C} 135353$ & 7.85 & & 19.625 \\
& $\mathrm{C} 135354$ & 14.84 & & 16.875 \\
& $\mathrm{C} 135355$ & 9.9 & & 24.750 \\
\hline
\end{tabular}

Tabel 1 merupakan tabel contoh perhitungan volume bijih nikel dengan mengambil 6 titik sampel dari 160 titik lubang bor pada daerah penelitian untuk masing - masing setiap lapisan limonit dan lapisan saprolit. Perhitungan volume sisa titik - titik lubang bor lainnya untuk setiap lapisan dihitung pada Ms. Excel 2013. Setelah dilakukan perhitungan volume bijih nikel untuk setiap titik lubang bor, maka diperoleh volume bijih nikel sebesar $816.675 \mathrm{~m}^{3}$ pada lapisan limonit dan volume bijih nikel sebesar 2.097.007 $\mathrm{m}^{3}$ pada lapisan saprolit. Setelah itu dilakukan perhitungan total untuk kedua lapisan dengan menggunakan persamaan 3 .

Hasil perhitungan volume bijih nikel untuk setiap titik lubang bor (160 titik) pada lapisan limonit dan saprolit memiliki jumlah total volume yang berbeda. Total volume bijih nikel pada lapisan saprolit lebih besar jika dibandingkan dengan total volume bijih nikel pada lapisan limoit, hal ini disebabkan karena nikel yang terendapkan lebih banyak pada lapisan saprolit.

\section{KESIMPULAN}

Identifikasi Sebaran Nikel Laterit
Volume 3 No.1, Maret, 2021

ISSN Online 2775 - 4529
1. Berdasarkan peta sebaran nikel, penyebaran nikel tertinggi pada daerah pertambangan PT. Vale Indonesia berada pada lapisan saprolit dengan ketebalan endapan nikel yang berbeda - beda karena adanya pengaruh topografi daerah penelitian.

2. Hasil perhitungan total volume bijih nikel untuk lapisan limonit dan saprolit dari 160 titik lubang bor, diperoleh total volume sebesar $2.913 .682 \mathrm{~m}^{3}$. Berdasarkan volume ini maka dapat dijadikan acuan eksplorasi penambangan nikel.

\section{DAFTAR PUSTAKA}

[1] Syafrizal, Heriawan M. Nur, et.al., 2009, "Hubungan Kemiringan Lereng dan Morfologi dalam Distribusi Ketebalan Horizon Laterit pada Endapan Nikel Laterit : Studi Kasus Endapan Nikel Laterit di Pulau Gee dan Pulau Pakal, Halmahera Timur, Maluku Utara" in International Conference Earth Science and Technology, 2009, Yogyakarta, Indonesia, vol : XVI No. 3.

[2] A. Waheed, 2005, Laterite : Fundamental of Chemistry, Mineralogy, Weathering Processes and Laterit formation. Sorowako, South Sulawesi : PT. International Nickel Indonesia.

[3] Sukandarrumidi, 2007, Geologi Mineral Logam. Yogyakarta : Gadjah Mada University

[4] Kementrian Energi dan Sumber Daya Mineral, "Peluang Investasi Nikel Indonesia", 2020. (online). Tersedia https://www.esdm.go.id/id/booklet/booklettambang-nikel-2020

[5] S. Widodo, Anshariah, and F. Astaman Masulili, 2015, "Studi Perbandingan Antara Metode Poligon dan Inverse Distance Pada Perhitungan Cadangan di PT.Cipta Mandiri Putra Perkasa Kabupaten Morowali" J. Geomine, vol. 3, no. 1, doi : $10.33536 /$ jg.v3i1.16

[6] N. Jafar, 2017, "Test Pit di Kecamatan Kabaena Kabupaten Bombana Provinsi Sulawesi Tenggara" J. Geomine, vol. 5, no. 2, doi : 
Paulus Civil Engineering Journal

E- Jurnal Teknik Sipil UKI-Paulus Makassar

http://ojs.ukipaulus.ac.id/index.php/pcej

10.33536/jg.v5i2.134

[7] R. Mustika, 2015, "Estimasi Sumberdaya Nikel Laterit Dengan Metode Inverse Distance Weighting (IDW) pada PT. Vale Indonesia, tbk. Kecamatan Nuha Provinsi Sulawesi Selatan" J. Geomine, vol. 1, no. 1, doi : 10.33536/jg.v1i1.11

[8] Hasria, E. Anshari and T. Binajaya Rezky, 2019, "Pengaruh Batuan Dasar dan Geomorfologi Terhadap Laterisasi dan Penyebaran Kadar Ni dan Fe Pada Endapan Nikel laterit PT. Tambang Bumi Sulawesi, Desa Pongkalaero, Kabupaten Bombana, Sulawesi Tenggara" J. Geografi Aplikasi dan Teknologi, vol : 3, no : 1, doi : $10.5281 /$ zenodo.3355821
Volume 3 No.1, Maret, 2021

ISSN Online 2775 - 4529

[9] S. Pratiwi, 2010, Perhitungan Cadangan Bijih Nikel Laterit Dengan Menggunakan Metode Poligon Pada Bukit TLA4 Daerah Tambang Tengah PT. Aneka Tambang Tbk. Kecamatan Pomalaa Kabupaten Kolaka Provinsi Sulawesi Tenggara, Makassar : Universitas Hasanuddin 